\title{
Pollution Assessment of Heavy Metals in Soils and Plants around a Molybdenum Mine in Central China
}

\author{
Zhangxiong Han ${ }^{1,2}$, Dejun Wan ${ }^{3}$, Haixia Tian ${ }^{1}$, Wenxiang He${ }^{1 *}$, \\ Ziquan Wang ${ }^{1}$, Qiang Liu ${ }^{2}$
}

${ }^{1}$ College of Natural Resources and Environment, Northwest A\&F University, Key Laboratory of Plant Nutrition and Agro-environment in Northwest China, Ministry of Agriculture, Yangling, Shaanxi, China

${ }^{2}$ Provincial Key Laboratory of Mineral Exploration and Utilization, Shaanxi, Xi'an Testing and Quality Supervision Center for Geological and Mineral Products, Ministry of Land and Resources, Xi'an, Shaanxi, China ${ }^{3}$ Institute of Hydrogeology and Environmental Geology, Chinese Academy of Geological Sciences,

Shijiazhuang, China

Received: 16 November 2017

Accepted: 22 January 2018

\begin{abstract}
Although environmental problems caused by metal mining have become increasingly prominent, the pollution by associated heavy metals is easily neglected. In general, molybdenum mines are lowgrade and hence the high level of associated heavy metals easily causes pollution in the surrounding areas. Here we investigated the total concentrations and forms of Mo and associated $\mathrm{Cu}, \mathrm{Cd}, \mathrm{Pb}$, and $\mathrm{Zn}$ in soils under different land-use types (barren, wheat, rape, and apple-seedling fields) and different plants (cultivated crops and wild wormwood) around an abandoned molybdenum tailings site. The results showed that the average total concentrations of $\mathrm{Cu}$ and $\mathrm{Zn}$ in farmland bulk soils around the site exceeded the level II standard of the National Environmental Quality Standard for Soils in China, the average Cd and $\mathrm{Pb}$ concentrations exceeded the level III standard, and the average Mo concentration exceeds the soil background value in Shaanxi Province. The percentages of available heavy metals in wormwood and seedling rhizosphere soils were significantly higher than those in crop rhizosphere soils. Heavy metals mainly accumulated in the roots of plants tested in this study. The $\mathrm{Cu}, \mathrm{Cd}$, and $\mathrm{Pb}$ concentrations in wormwood exceeded the limits of these metals in general plants. The $\mathrm{Cd}$ and $\mathrm{Pb}$ pollution indices of corn at the side of the barren land were 3.12 and 2.48, respectively, and the $\mathrm{Pb}$ pollution index of rape was 3.42, according to the standard limit of pollutants in food for China. On the basis of the level III standard, the pollution assessment of soils revealed serious pollution of the barren land and wheat fields, and moderate pollution of the rape and seedling fields. This study indicates that the heavy metals associated with
\end{abstract}

*e-mail: wenxiang.he@nwafu.edu.cn 
the molybdenum mine have polluted the surrounding soils and plants, of which pollution of the barren land is the most serious.

Keywords: molybdenum mine, heavy metal pollution, bulk soil, rhizosphere soil, plants

\section{Introduction}

The development of mineral resources has created enormous material wealth, but it has also brought with it a series of ecological and environmental problems, such as soil, groundwater, and atmospheric pollution. Heavymetal pollution has become a serious environmental problem around mining areas [1-3]. Studies of heavymetal pollution in mining areas have mainly focused on the mined elements [4]; the associated heavy metals, which are important environmental pollutants that lower the mining grade, have mostly been ignored. In China, heavy-metal mineral resources are widely distributed in rich minerals and reserves, and most of these resources have associated heavy-metal pollutants. Studying the influence of these associated heavy-metal pollutants and their interactions with plants can reveal the pollution of the mining area more accurately.

In general, molybdenum mines are low grade, even if a molybdenum-nickel mine has higher contents of Mo within the range of $0.20-8.17 \%$ [5-6]. The heavy-metal pollutants associated with molybdenum mines include various valuable elements, such as $\mathrm{Cu}, \mathrm{W}, \mathrm{Au}, \mathrm{Ag}, \mathrm{Fe}$, $\mathrm{Pb}, \mathrm{Cd}$, and $\mathrm{As}$, of which $\mathrm{Cd}, \mathrm{Cu}$, and $\mathrm{Pb}$ are major pollutants of the molybdenum mine [8]. In the mining process, many associated heavy metals may enter the soil with differentiation of the slag. $\mathrm{Cd}, \mathrm{Pb}$, and other heavy metals are usually piled up with the tailings slag in the molybdenum mining area [7]. If these elements are handled improperly, they can enter into the soil, and when their soil concentration exceeds a certain limit, these elements cause plant stress.

Plant availability, toxicity, migration, and transformation abilities of heavy metals associated with molybdenum mines are all related to their existing forms [8-9]. Through weathering, rainwater dripping, and filtration, the soluble fraction of heavy metals in the tailings slag diffuses to the interface with the atmosphere or water flow and then enters into the soils and water bodies, polluting the soils and plants. Such pollution is mainly caused by the water-soluble, exchangeable form and carbonate-bound form of toxic metals [10]. Therefore, analysis of the form of associated heavy metals in bulk soils, rhizosphere soils, and plants around molybdenum mines is necessary to reveal the transport mechanism of these metals between soils and plants, and further provide evidence for implementing governance schemes for polluted soils.

To date, studies of heavy-metal pollution in molybdenum mines have mainly focused on the environmental problems caused by mining activity [11] and the total amount of heavy-metal pollutants in the mining area [7]. The distribution of major heavy metals (e.g., $\mathrm{Cu}, \mathrm{Cd}, \mathrm{Pb}$, and $\mathrm{Zn}$ ) associated with the molybdenum mine is unclear in bulk soils with different uses, rhizosphere soils, and plants. To reveal the mechanism of heavy-metal pollution in the molybdenum mining area clearly, we must further study: (1) the existing forms of Mo and the associated heavy metals and their variations in bulk soils and rhizosphere soils around the molybdenum mining area, and the distribution and form changes of these elements after entering into plants; and (2) the influence of Mo on the associated heavy metals in the stress process of plants and its transport mechanism from soils to plants.

The reserves of the molybdenum mines in Shaanxi Province account for $13.6 \%$ of the total national reserves, ranking second in China [12]. Despite long-term extensive mining, there are relatively few studies on the pollution mechanisms of the heavy metals associated with the molybdenum tailings. Existing studies have not fully considered the action mechanism of Mo on the associated heavy metals, or the influence of different land-use types on the soils [7], making it difficult to make comprehensive use of molybdenum tailings. Luonan is an important molybdenum mining area in Shaanxi Province. Studies in this area have focused on the supergene geochemical characteristics of heavy metals in the tailings slag [7]. There are no studies on the distribution of the different forms of these heavy metals in bulk soils and rhizosphere soils, and their ecological function in crops, or pollution assessments of the soil environment and crops after the toxic metals have entered the crop system.

In this study, we analyzed the total concentrations and existing forms of Mo and associated heavy metals $(\mathrm{Cu}$, $\mathrm{Cd}, \mathrm{Pb}$, and $\mathrm{Zn}$ ) in bulk soils with different farmlanduse types, rhizosphere soils, and plants around a typical molybdenum mining area (Huanglongpu molybdenum mine) in Luonan. We investigated their migration characteristics in the soil-plant system and explored the transport mechanism between the soils and plants. A pollution assessment of the associated heavy metals was conducted to provide technical support for the governance and remediation of soil pollution in molybdenum mines and similar areas. The results have broad application prospects.

\section{Materials and Methods}

\section{Site Description}

The study area is located in Huanglongpu, Luonan, Shaanxi Province $\left(34^{\circ} 22^{\prime} \mathrm{N}, 110^{\circ} 01^{\prime} \mathrm{E}\right)$. It is in the north temperate zone, which has a warm-temperate humid climate. The average annual temperature, annual 
precipitation, and soil $\mathrm{pH}$ are $11.5^{\circ} \mathrm{C}, 754.8 \mathrm{~mm}$, and 7.20, respectively. The Huanglongpu molybdenum mining area was developed for mining from the 1970s, and most mines have now been abandoned. There are many agricultural fields around the mining area, and the soil is dominated by yellow brown soil. Crops are mainly rape, wheat, corn, and potatoes, of which rape and wheat are the most typical species.

\section{Sample Collection and Processing}

We selected 3 barren lands, 4 wheat fields, 3 rape fields, and 3 apple-seedling fields, with areas of $500-1,000 \mathrm{~m}^{2}, 1,200-4,000 \mathrm{~m}^{2}, 600-2,000 \mathrm{~m}^{2}$, and $3,000-5,000 \mathrm{~m}^{2}$, respectively, for each field. All fields were within $2 \mathrm{~km}$ of the mining area. At the end of May 2014, we collected 0-20 cm soil samples from each field with an auger ( $8 \mathrm{~cm}$ inner diameter), as well as plant samples manually. Corn was collected $15 \mathrm{~d}$ later due to different ripening times of the crops. Bulk soils were collected from the barren land and between two ridges of wheat, rape, or 1.5-year-old apple seedlings. Rhizosphere soils were obtained from $0-4 \mathrm{~mm}$ soil of plant roots. Cultivated plants commonly grown in the local area were sampled, including corn (Zea mays L.) variety Yuanyu 16 (at the side of barren land), wheat (Triticum aestivum L.) variety Xiaoyan 22, rape (Vitis vinifera L.) variety Zaqin Rape No.1, and apple (Malus domestica) variety M9T337. Wormwood (Artemisia absinthium) was collected as a wild plant.

At each sampling site, 3 soil samples and 4 plants (cultivated or wild) were collected at random and mixed into one sample. After air drying and impurity removal, soil samples were broken into pieces, ground, and passed through a 100-mesh nylon sieve into a plastic bottle. The same procedure was performed for bulk and rhizosphere soils. Corn, wheat, and rape plants were divided into root, shoot, and grain, while wormwood plants and apple seedlings were divided into root and shoot. Each portion of plant samples was rinsed repeatedly with deionized water to remove surface dust. The plant samples were deactivated in an oven at $80^{\circ} \mathrm{C}$ for $30 \mathrm{~min}$ and then dried at $60^{\circ} \mathrm{C}$ until the weight was constant. Dry plant samples were crushed with a plastic crusher and passed through a 100-mesh sieve into a plastic bottle.

\section{Heavy-Metal Analysis}

Heavy metals in the soil samples were analyzed by $\mathrm{HNO}_{3}-\mathrm{HClO}_{4}-\mathrm{HF}-\mathrm{HCl}$ tetracid digestion and inductively coupled plasma mass spectrometry [13]. Each metal form in the soil samples was analyzed by Tessier's sequential extraction [14], including the exchangeable form ( $\mathrm{F} 1$, extracted with $8 \mathrm{~mL}$ of $1 \mathrm{M} \mathrm{MgCl}_{2}, \mathrm{pH} 7.0$ ), carbonate-bound form (F2, extracted with $8 \mathrm{~mL}$ of $1 \mathrm{M} \mathrm{NaOAc}, \mathrm{pH}$ 5.0), amorphous Fe-Mn oxide form (F3, extracted with $20 \mathrm{~mL}$ of mixture of $0.3 \mathrm{M} \mathrm{Na}_{2} \mathrm{~S}_{2} \mathrm{O}_{4}$, $0.175 \mathrm{M} \mathrm{Na}$-citrate and $0.025 \mathrm{M} \mathrm{H}$-citrate), organic-bound form (F4, extracted with $3 \mathrm{~mL}$ of $0.02 \mathrm{M} \mathrm{HNO}_{3}$ and $5 \mathrm{~mL}$ of $30 \% \mathrm{H}_{2} \mathrm{O}_{2}, \mathrm{pH} 2.0$ ), and residual form ( $\mathrm{F} 5$, extracted with a HF-HC1O mixture). Soil $\mathrm{pH}$ was measured at a 1:2 soil-to- $0.01 \mathrm{M} \mathrm{CaCl}_{2}$ ratio with an INESA model PHS-3C pH meter (Shanghai, China). Soil organic matter content was determined by the loss-on-ignition method and samples were ashed in the HONGJI Type SX-4-10 Muffle furnace for $4 \mathrm{~h}$ at $450^{\circ} \mathrm{C}$ [15].

Plant samples were pretreated by microwave digestion [16]. Samples of $0.5000 \mathrm{~g}$ were weighed into a microwave digestion tank, and $10 \mathrm{~mL}$ of guaranteed pure nitrate was added. Samples were incubated overnight. Then 2 $\mathrm{mL}$ of guaranteed pure hydrogen peroxide was added and the samples were placed into a microwave digestion system (Ethos A, Milestone, Italy). The temperature was increased gradually using the microwave digestion procedure until the sample became clear. The digested sample was transfer into a $50 \mathrm{~mL}$ colorimetric tube containing ultrapure water (GN-RO-250-type ultrapure water machine, Shuangfeng Zhongbang Technology Development Co., Ltd., Beijing, China). $\mathrm{Cd}, \mathrm{Cu}, \mathrm{Pb}, \mathrm{Zn}$, and Mo concentrations in plant samples were measured by an inductively coupled plasma source mass spectrometer (iCAP 6300, Thermo Fisher Scientific, Wilmington, DE USA).

\section{Data Analysis}

(1) Single pollution index [17-18]:

$$
P_{i}=c_{i} / S_{i}
$$

...where $P_{i}$ is the pollution index of a single heavy metal $i$ in the soil, $c_{i}$ is the concentration of a single heavy metal $i$ in the soil, and $S_{i}$ is the assessment standard of a single heavy metal $i$. When $P_{i}<1$, the soil is not polluted by the heavy metal, and when $P_{i}>1$, the soil is polluted. The greater the $P_{i}$ value, the more serious the pollution.

(2) Nemerow pollution index [19]

The single pollution index only represents environmental quality with regard to one heavy metal; it does not reflect overall environmental quality. The Nemerow pollution index was therefore used to assess comprehensive pollution:

$$
P_{\text {comprehensive }}=\sqrt{\frac{\left(\mathrm{Pmax}^{2}+\mathrm{Pave}^{2}\right)}{2}}
$$

...where $P_{\text {comprehensive }}$ is the Nemerow pollution index, $P_{\max }$ is the maximum of the single pollution index, and $P_{\text {ave }}$ is the average of the single pollution index in the assessment. The soil environmental quality standard of the comprehensive pollution index is: $P_{\text {comprehensive }}<0.7$, clean (security level); $P_{\text {comprehensive }}=0.7-1.0$, warning limit; $P_{\text {comprehensive }}=1.0-2.0$, mild pollution; $P_{\text {comprehensive }}=$ 2.0-3.0, moderate pollution; and $P_{\text {comprehensive }}>3.0$, serious pollution. 
(3) Enrichment coefficient [20]: the ratio of heavymetal concentration in plants and soils represents the enrichment capacity of plants for heavy metals:

$$
\mathrm{E}_{\mathrm{c}}=\mathrm{C}_{\mathrm{p}} / \mathrm{C}_{\mathrm{s}}
$$

...where $\mathrm{E}_{\mathrm{c}}$ is the enrichment coefficient, $\mathrm{C}_{\mathrm{p}}$ is the heavy metal content in plants, and $\mathrm{C}_{\mathrm{s}}$ is the heavy metal content in soil.

(4) Transfer coefficient [21]: the ratio of heavy-metal concentration in plant shoots and roots represents the capacity of heavy metals to be transported from the roots to shoots:

$$
\mathrm{T}_{\mathrm{c}}=\mathrm{C}_{\mathrm{sh}} / \mathrm{C}_{\mathrm{r}}
$$

...where $\mathrm{T}_{\mathrm{c}}$ is the transfer coefficient, $\mathrm{C}_{\mathrm{sh}}$ is the heavy metal content in shoots of plants, and $\mathrm{C}_{\mathrm{r}}$ is the heavy metal content in roots of plants.

One-way analysis of variance was conducted at $P<0.05$, followed by a multiple comparison least significant difference test. Statistical analysis and figure drawing were performed using SPSS Statistics 18.0 (SPSS Inc., Chicago, IL, USA) and Excel 2003 (Microsoft Corp., Redmond, WA, USA).

\section{Results and Discussion}

\section{Variations in Heavy-Metal Concentrations in Soils}

The total heavy-metal concentrations in soils with different land-use types around the molybdenum mining area are shown in Table 1. Soil $\mathrm{Cu}$ concentrations in the barren land, wheat, and rape fields were significantly lower than those in the seedling field. Soil Cd concentration showed the opposite trend and the concentrations in the rape and seedling fields were significantly lower than those in the barren land and wheat field. There were no significant differences in soil $\mathrm{Pb}$ concentration between the wheat and rape fields, both of which were significantly lower than the concentrations in the barren land and seedling field. Soil Mo and $\mathrm{Zn}$ concentrations in the barren land were the highest, with no significant differences between the other land-use types.

Soil $\mathrm{Cu}$ and $\mathrm{Pb}$ concentrations in the seedling field ranked the highest, which reached 18.7 and 52.6 times the soil background value in Shaanxi Province, and 11.5 and 31.7 times the National Environmental Quality Standard for Soils in China, respectively. The highest soil concentrations of $\mathrm{Cd}, \mathrm{Zn}$, and Mo were found in the barren land, which reached 61.8, 7.16, and 14.4 times the soil background value in Shaanxi Province, respectively. The soil concentrations of $\mathrm{Cd}$ and $\mathrm{Zn}$ were 37.1 and 4.97 times higher than the National Environmental Quality Standard, respectively. The average total concentrations of the different heavy metals were as follows: Cu $270 \mathrm{mg} \cdot \mathrm{kg}^{-1}, \mathrm{Cd} 4.47 \mathrm{mg} \cdot \mathrm{kg}^{-1}, \mathrm{~Pb} 881 \mathrm{mg} \cdot \mathrm{kg}^{-1}$, Mo $193 \mathrm{mg} \cdot \mathrm{kg}^{-1}$, and $\mathrm{Zn} 406 \mathrm{mg} \cdot \mathrm{kg}^{-1}$. All of these values exceeded the background value of the National Environmental Quality Standard and the soil background value in Shaanxi Province [22].

The above results indicate that the soils in the study area suffer different levels of heavy-metal pollution, and the pollution status of the different heavy metals varies among sampling sites. This is consistent with the results of Zhong [23], who investigated heavy-metal pollution of soils under different farmland-use types in Xuwen County, Guangdong Province, China. The heavy-metal concentrations in the soils around the molybdenum mining area are related to land-use type, and there are differences among the various land-use types. The variable coefficients of heavy metal concentrations among land-use types ranked $\mathrm{Cd}>\mathrm{Cu}>\mathrm{Pb}>\mathrm{Mo}>\mathrm{Zn}$ (Table 1). This indicates that $\mathrm{Cd}$ soil pollution around the molybdenum mining area is most affected by landuse type. As reported, land use type and agricultural management practices could affect soil quality through altering soil physical and chemical properties and in the soil biotic community, which then influence heavy metal accumulation [24]. Our result is in agreement with the

Table 1 . Heavy metal concentrations of soils with different land use types around the molybdenum mine $\left(\mathrm{mg} \cdot \mathrm{kg}^{-1}, \mathrm{n}=3\right)$.

\begin{tabular}{|c|c|c|c|c|c|}
\hline Items & $\mathrm{Cu}$ & $\mathrm{Cd}$ & $\mathrm{Pb}$ & $\mathrm{Mo}$ & $\mathrm{Zn}$ \\
\hline Barren land & $265 \pm 10 \mathrm{a}$ & $7.4 \pm 0.2 \mathrm{a}$ & $998 \pm 6 \mathrm{a}$ & $287 \pm 11 \mathrm{a}$ & $497 \pm 10 \mathrm{a}$ \\
\hline Wheat field & $211 \pm 15 \mathrm{a}$ & $4.95 \pm 0.26 \mathrm{ab}$ & $736 \pm 21 \mathrm{~b}$ & $193 \pm 7 \mathrm{~b}$ & $414 \pm 12 \mathrm{~b}$ \\
\hline Rape field & $203 \pm 11 \mathrm{a}$ & $2.90 \pm 0.38 \mathrm{~b}$ & $664 \pm 19 \mathrm{~b}$ & $190 \pm 4 \mathrm{~b}$ & $387 \pm 10 \mathrm{bc}$ \\
\hline Apple seedling field & $401 \pm 11 \mathrm{~b}$ & $2.62 \pm 0.35 \mathrm{c}$ & $1126 \pm 26 \mathrm{a}$ & $201 \pm 10 \mathrm{~b}$ & $426 \pm 11 \mathrm{~b}$ \\
\hline Average & 270 & 4.47 & 881 & 193 & 406 \\
\hline Variable coefficient/\% & 28.6 & 49.6 & 24.7 & 6.00 & 4.26 \\
\hline $\begin{array}{c}\text { Background value of National Environmental Quality } \\
\text { Standard for Soils in China (GB 15618-1995) }\end{array}$ & 35.0 & 0.12 & 21.4 & 20.0 & 69.4 \\
\hline
\end{tabular}

Note: Lowercase letter represents significant difference of the same heavy metal between different land use types $(\mathrm{P}<0.05$, by LSD test) 

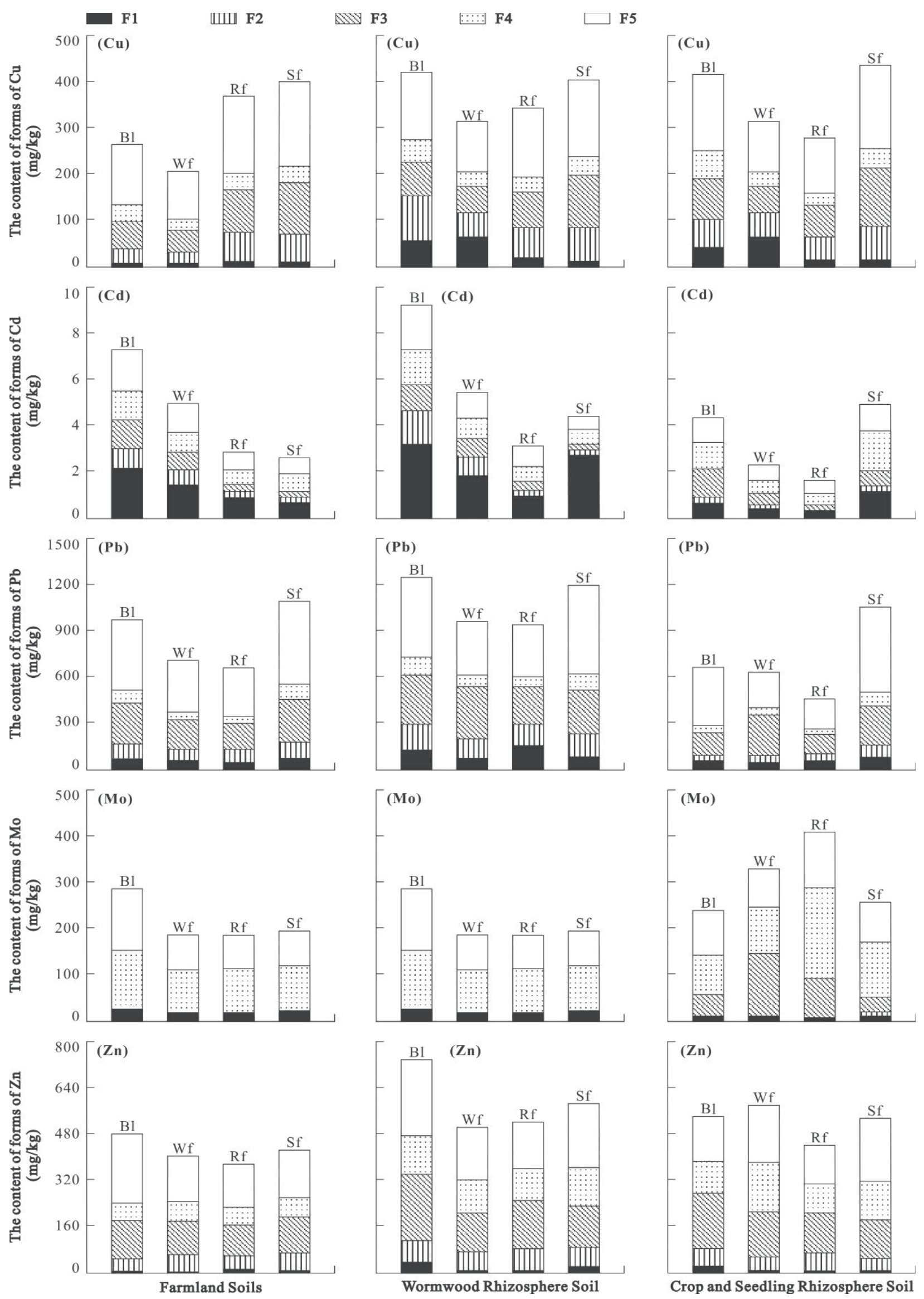

Fig. 1. Concentrations of different forms of heavy metals in bulk and rhizosphere soils with different farmland land use types; note: Sampling sites - Bl (Barren land), Wf (Wheat field), Rf (Rape field), and Sf (Seedling field); metal forms - F1, exchangeable form; F2, carbonate-bounded form; F3, amorphous Fe-Mn oxide form; F4, organic-bound from, and F5, residual form. 
findings of Xiao [25] for heavy-metal pollution in orchard soils around a molybdenum mining area.

\section{Variations in Heavy-Metal Forms in Soils}

The forms of heavy metals present in soils around the molybdenum mine differed among the various land-use types (Fig. 1). Under the different farmland use types, there were differences in the percentage of specific forms in the total concentration of heavy metals between bulk soil, rhizosphere soil, and different rhizosphere soils. For 5 heavy metals, there were different chemical speciation distributions even with the same land use, which were consistent with previous studies [26-27]. The available forms of Mo and $\mathrm{Zn}(\mathrm{F} 1+\mathrm{F} 2)$ in each field made up the smallest percentage, after the available forms of $\mathrm{Cu}$ and $\mathrm{Pb}$. The available forms of $\mathrm{Cd}$ accounted for the largest percentage in each field. This indicates that $\mathrm{Cd}$ has the highest activity in soils around the mining area and has the greatest possibility for soil pollution, in agreement with the finding of Guo et al. [28] from polluted urban soils.

The total $\mathrm{Cu}$ concentrations in wheat and rape fields were lower than those in the barren land and seedling fields. For all tested soils, $\mathrm{Cu}$ were predominantly associated with the residual fraction (F5), which is similar to the previous study [26]. The percentage of available $\mathrm{Cu}$ in wormwood and crop rhizosphere soils was significantly higher than that in bulk soils, and there was no significant difference in available $\mathrm{Cu}$ between wormwood and crop rhizosphere soils. As it is known, rhizosphere soils generally have distinct soil properties compared with bulk soils, which indirectly affect heavy metal distribution [29-30]. In bulk soils, available $\mathrm{Cu}$ accounted for the largest percentage in the rape field; in rhizosphere soils, the percentage of available $\mathrm{Cu}$ in wormwood rhizosphere soils was the highest (Fig. 1).

The total $\mathrm{Cd}$ concentration in farmland bulk soils, wormwood rhizosphere soils, and seedling rhizosphere soils was higher than that in crop rhizosphere soils. The dominant $\mathrm{Cd}$ fraction changed as the land uses altered, which is different with the $\mathrm{Cu}$ speciation distribution. The similar results were also reported that $\mathrm{Cd}$ dominant fraction was different among various soils [31]. The percentage of available $\mathrm{Cd}$ also differed between bulk soils and rhizosphere soils. The percentage of available $\mathrm{Cd}$ ranked barren land $>$ wheat field $>$ rape field $>$ seedling field in bulk soils; seedling field $>$ barren land $>$ wheat field $>$ rape field in wormwood rhizosphere soils; and seedling field $>$ wheat field $>$ barren land $>$ rape field in crop rhizosphere soils (Fig. 1).

Total $\mathrm{Pb}$ concentration was highest in wormwood rhizosphere soils and lowest in crop rhizosphere soils. The dominant fraction of $\mathrm{Pb}$ also changed with different land uses. However, it was found that in B1 and Sf, $\mathrm{Pb}$ mainly existed as the exchangeable form, which might be determined by their low organic matter content $(\sim 9 \mathrm{~g} / \mathrm{kg})$. The percentage of available $\mathrm{Pb}(\mathrm{F} 1+\mathrm{F} 2)$ was the highest in rape rhizosphere soils. The total concentration of Mo in bulk soils was lower than that in wormwood and crop rhizosphere soils. The percentage of available Mo was lowest in crop rhizosphere soils. The percentage of available Mo in the rape field was significantly lower than that in the other 3 types of fields. The differences in total $\mathrm{Zn}$ concentration were similar to those for the Mo concentration, with the highest concentration in wormwood rhizosphere soils, followed by crop rhizosphere soils, and lowest in bulk soils. The percentage of available $\mathrm{Zn}$ in wormwood rhizosphere soils was the highest (Fig. 1).

There were differences in the heavy-metal forms between bulk soils and rhizosphere soils. The concentration of available heavy metals in wormwood rhizosphere soils was significantly higher than that in crop rhizosphere soils, which indicates the potential of the wormwood rhizosphere environment for activating and absorbing heavy metals in soils to a large extent. Wormwood is considered to be a plant with high resistance to heavy metals [32]. The concentration of available heavy metals in crop rhizosphere soils was relatively low, which indicates that the rhizosphere soil environment of crops is unfavorable for activating heavy metals. This is consistent with the study of MartínezAlcalá et al. [33], and also explains why the soil around the mining area is polluted, but the crops are not. The reason for the high total concentration of Mo and the low percentage of available Mo in crop rhizosphere soil may be that the crops maintain Mo and other heavy metals in a stable combined state in the rhizosphere environment, and thus reduce the pollution of heavy metals.

\section{Pollution Status of Soils}

From the above analysis, we conclude that the main heavy-metal pollutants in the soils of the study area are $\mathrm{Cu}, \mathrm{Cd}, \mathrm{Pb}, \mathrm{Mo}$, and $\mathrm{Zn}$. This is consistent with the pollutant elements previously found in the soils around molybdenum mining areas [25, 34]. Mo is an essential element for plants, but there is no standard level for this element in the National Environmental Quality Standard for Soils in China [35]. Thus, we use the 4 associated heavy metals, $\mathrm{Cu}, \mathrm{Cd}, \mathrm{Pb}$, and $\mathrm{Zn}$, in soils around the molybdenum mining area for the pollution assessment indices in this study. Based on the assessment standard for soils around the mining area (Table 2), bulk soils were determined to be at the level III standard (there is no level III standard for $\mathrm{Cd}$, so level II standard was used), and

Table 2. National environmental quality standard for soils in China (GB 15618-1995) $\left(\mathrm{mg}^{\mathrm{kg}} \mathrm{kg}^{-1}\right)$.

\begin{tabular}{|c|c|c|c|c|c|}
\hline Level & $\mathrm{pH}$ & $\mathrm{Cu}$ & $\mathrm{Cd}$ & $\mathrm{Pb}$ & $\mathrm{Zn}$ \\
\hline Level I & $\begin{array}{c}\text { Natural } \\
\text { background }\end{array}$ & 35 & 0.2 & 35 & 100 \\
\hline Level II & $<6.50$ & 50 & 0.3 & 250 & 200 \\
\hline Level III & $>6.50$ & 400 & 1.0 & 500 & 500 \\
\hline
\end{tabular}


Table 3. $\mathrm{pH}$, organic matter content, and pollution indices of soils at different sampling sites around the mine tailings.

\begin{tabular}{|c|c|c|c|c|c|c|c|}
\hline Sampling site & $\mathrm{pH}$ value & Organic matter content $(\mathrm{g} / \mathrm{kg})$ & $\mathrm{P}_{\mathrm{Cu}}$ & $\mathrm{P}_{\mathrm{Cd}}$ & $\mathrm{P}_{\mathrm{Pb}}$ & $\mathrm{P}_{\mathrm{Zn}}$ & $\mathrm{P}_{\text {comprehensive }}$ \\
\hline Barren land & 5.82 & 8.6 & 0.66 & 7.41 & 2.00 & 0.99 & 5.59 \\
\hline Wheat field & 7.62 & 18.3 & 0.53 & 4.95 & 1.47 & 0.83 & 3.76 \\
\hline Rape field & 6.21 & 12.4 & 0.51 & 2.90 & 1.33 & 0.77 & 2.27 \\
\hline Apple seedling field & 6.08 & 9.6 & 1.01 & 2.62 & 2.25 & 0.85 & 2.20 \\
\hline
\end{tabular}

the pollution of soils was assessed using the single and comprehensive (Nemerow) pollution indices.

As Table 3 shows, the average single pollution index in soils around the molybdenum mining area ranked $\mathrm{Cd}>\mathrm{Pb}>\mathrm{Zn}>\mathrm{Cu}$. This indicates that the soils around the molybdenum mining area are mainly polluted by $\mathrm{Cd}$ and $\mathrm{Pb}$. The single pollution index of $\mathrm{Cu}$ in the soil of the seedling field slightly exceeded the limit, and there was no $\mathrm{Cu}$ pollution in soils in the other fields. Zn was not a soil pollutant in any of the fields. In terms of the comprehensive pollution index, all 4 types of fields were polluted moderately or severely, ranking barren land $>$ wheat field $>$ rape field $>$ seedling field. The comprehensive pollution index was greater than 3 in soils of the barren land and wheat field, indicating severe pollution. The comprehensive pollution index was as high as 5.59 in soil of the barren land. The comprehensive pollution index was within the range of 2-3 in the rape and seedling fields, indicating moderate pollution.

Regardless of the pollution index used, the results showed that the soils around the molybdenum mining area are polluted by heavy metals in different degrees. Combined with the pollution of crops, we conclude that soils have been polluted severely by heavy metals around the molybdenum mining area, but wheat is not polluted. This may be because the edible parts of crops tested in this study are grains, and wheat can reduce heavy-metal damage to its grains by filtering via the root, stem, and leaf [36]. Taking into account the local soil conditions, we note that the $\mathrm{pH}$ value is greater than 6.5 with a high organic matter content. Soil organic matter and $\mathrm{pH}$ may influence the transfer and transformation of heavy metals in soils, and a high $\mathrm{pH}$ value and organic matter content can immobilize heavy metals in soils [10, 26]. This result also highlights the risk of associated heavy-metal pollution to surrounding soils when exploiting a mine with many associated elements.

\section{Variations in Heavy-Metal Concentrations in Plants}

The crops, corn, wheat, and rape showed different levels of heavy-metal absorption, and the heavy-metal concentrations in different parts of the crops ranked root $>$ shoot $>$ grain (Table 4 ). The path of elements from the soil into vegetative and reproductive organs of a plant can be structured into distinct processes that vary in relevance depending on, for instance, plant species, habitat, the developmental state, and the tissue in question [37]. The total concentrations of heavy metals in corn were higher than those in wheat and rape, as were the concentrations in the different parts of corn. The total concentrations of $\mathrm{Cu}, \mathrm{Pb}$, and $\mathrm{Cd}$ in wheat were the lowest, and the grain concentrations of these 3 elements were lowest in rape. The concentrations of these 3 elements in the shoots and roots of rape were higher than those in wheat, while the concentrations of Mo and $\mathrm{Zn}$ in the different parts of wheat were higher than those in rape.

According to the Food Security Standard for Limit of Pollutants in China (GB 2762-2017) [38], the standard

Table 4. Heavy metal concentrations in different parts of cultivated crops at the sampling sites $\left(\mathrm{mg} \cdot \mathrm{kg}^{-1}, \mathrm{n}=4\right)$.

\begin{tabular}{|c|c|c|c|c|c|c|}
\hline Crop & Plant part & $\mathrm{Cu}$ & $\mathrm{Cd}$ & $\mathrm{Pb}$ & $\mathrm{Mo}$ & $\mathrm{Zn}$ \\
\hline \multirow{4}{*}{ Corn } & Grain & $4.54 \pm 0.63$ & $0.156 \pm 0.0120$ & $0.476 \pm 0.009$ & $0.343 \pm 0.023$ & $13.7 \pm 1.0$ \\
\cline { 2 - 7 } & Shoot & $10.8 \pm 0.8$ & $1.22 \pm 0.086$ & $0.953 \pm 0.076$ & $2.90 \pm 0.78$ & $15.7 \pm 1.3$ \\
\cline { 2 - 7 } & Root & $57.0 \pm 4.2$ & $1.73 \pm 0.13$ & $2.97 \pm 0.07$ & $6.99 \pm 0.73$ & $27.8 \pm 0.5$ \\
\hline \multirow{4}{*}{ Wheat } & Grain & $3.24 \pm 0.64$ & $0.0235 \pm 0.007$ & $0.0853 \pm 0.012$ & $0.0576 \pm 0.01$ & $11.8 \pm 0.9$ \\
\cline { 2 - 8 } & Shoot & $8.86 \pm 0.97$ & $0.224 \pm 0.078$ & $0.204 \pm 0.014$ & $0.784 \pm 0.012$ & $14.8 \pm 1.8$ \\
\cline { 2 - 8 } & Root & $41.5 \pm 5.9$ & $0.382 \pm 0.065$ & $1.26 \pm 0.16$ & $2.77 \pm 0.97$ & $24.7 \pm 3.8$ \\
\hline \multirow{3}{*}{ Rape } & Grain & $1.34 \pm 0.12$ & $0.0132 \pm 0.005$ & $0.342 \pm 0.0119$ & $0.0243 \pm 0.007$ & $6.78 \pm 0.74$ \\
\cline { 2 - 7 } & Shoot & $9.35 \pm 0.74$ & $0.245 \pm 0.037$ & $0.535 \pm 0.018$ & $0.654 \pm 0.028$ & $13.8 \pm 1.3$ \\
\cline { 2 - 7 } & Root & $55.0 \pm 2.9$ & $0.423 \pm 0.053$ & $1.54 \pm 0.06$ & $1.75 \pm 0.26$ & $20.5 \pm 1.0$ \\
\hline
\end{tabular}


Table 5. Heavy metal concentrations in wild plants at the sampling sites $\left(\mathrm{mg}^{\mathrm{kg}} \mathrm{kg}^{-1}, \mathrm{n}=4\right)$.

\begin{tabular}{|c|c|c|c|c|c|}
\hline Items & $\mathrm{Cu}$ & $\mathrm{Cd}$ & $\mathrm{Pb}$ & Mo & $\mathrm{Zn}$ \\
\hline Barren land & $95.7 \pm 6.4$ & $4.77 \pm 0.59$ & $55.1 \pm 0.67$ & $11.9 \pm 0.59$ & $38.6 \pm 2.6$ \\
\hline Wheat field & $68.5 \pm 5.6$ & $2.71 \pm 0.48$ & $49.4 \pm 2.0$ & $13.6 \pm 1.9$ & $46.6 \pm 2.1$ \\
\hline Rape field & $130 \pm 9$ & $1.76 \pm 0.22$ & $35.4 \pm 4.0$ & $11.6 \pm 0.7$ & $41.3 \pm 1.4$ \\
\hline Apple seedling field & $179 \pm 12$ & $1.41 \pm 0.08$ & $68.2 \pm 1.0$ & $13.9 \pm 0.4$ & $53.8 \pm 1.6$ \\
\hline Limit range in plants ${ }^{[28]}$ & $5-30$ & $0.1-1.0$ & $0.1-10$ & / & $20-150$ \\
\hline Average & $118 \pm 8$ & $2.66 \pm 0.34$ & $52.0 \pm 1.9$ & $12.7 \pm 0.9$ & $45.1 \pm 1.9$ \\
\hline Variable coefficient $(\%)$ & 40.4 & 56.6 & 26.2 & 9.30 & 14.9 \\
\hline
\end{tabular}

limit for $\mathrm{Pb}$ and $\mathrm{Cd}$ in cereals is 0.2 and $0.1 \mathrm{mg} \cdot \mathrm{kg}^{-1}$, respectively, and the standard limit for $\mathrm{Pb}$ and $\mathrm{Cd}$ in oil crops is $0.1 \mathrm{mg} \cdot \mathrm{kg}^{-1}$. The $\mathrm{Pb}$ concentration in corn grain at the side of barren land was 2.48 times higher than the standard limit and the $\mathrm{Cd}$ concentration was 1.56 times higher than the standard limit. None of the heavy-metal concentrations in wheat exceeded the standard limits. The $\mathrm{Pb}$ concentration in rape grain was 3.42 times higher than the standard limit. These results indicate that the corn at the side of barren land has been polluted by $\mathrm{Pb}$ and $\mathrm{Cd}$, and the rape has been polluted by $\mathrm{Pb}$.

The concentration of heavy metals in wild plants (i.e., wormwood) around the molybdenum mine is related to land-use type (Table 5), with the average concentrations of $\mathrm{Cu}, \mathrm{Cd}, \mathrm{Pb}, \mathrm{Mo}$, and $\mathrm{Zn}$ being 118, 2.66, 52.0, 12.7, and $45.1 \mathrm{mg} \cdot \mathrm{kg}^{-1}$, respectively. The heavy-metal concentration in plants generally has an upper limit [39]. In the present study, the $\mathrm{Cu}$ concentrations in plants at all sampling sites exceeded the standard limit for general plants (5-30 mg $\left.\cdot \mathrm{kg}^{-1}\right)$. Cd concentrations in plants also exceeded the range for general plants $\left(0.1-1.0 \mathrm{mg} \cdot \mathrm{kg}^{-1}\right)$, with the highest level reaching $4.77 \mathrm{mg} \cdot \mathrm{kg}^{-1}$ in the barren land. In general, only a small amount of $\mathrm{Pb}$ accumulates in the aboveground part of plants, with a relatively narrow range of $0.1-10 \mathrm{mg} \cdot \mathrm{kg}^{-1}$ (2 $\mathrm{mg} \cdot \mathrm{kg}^{-1}$ on average). The $\mathrm{Pb}$ concentrations in plants at all 4 sampling sites exceeded the above range, indicating that wild plants have a higher ability to accumulate $\mathrm{Pb}$ than cultivated crops.

Mo is an essential element for plants and there has been no report of Mo concentrations in plants exceeding the standard limit [40]. The Mo concentration in wormwood at all sampling sites was relatively consistent, within the range of $11.6-13.9 \mathrm{mg} \cdot \mathrm{kg}^{-1} . \mathrm{Zn}$ is also an essential element for plant growth, but an excess of $\mathrm{Zn}$ can damage plants [41]. The $\mathrm{Zn}$ concentration in general plants ranged from 20 to $150 \mathrm{mg} \cdot \mathrm{kg}^{-1}$, covering the levels in wormwood, $38.6-53.8 \mathrm{mg} \cdot \mathrm{kg}^{-1}$. In terms of the variable coefficients, $\mathrm{Cu}$ and $\mathrm{Cd}$ ranked the highest in wormwood, with $40.4 \%$ and $56.6 \%$, respectively; the 2 elements are therefore distributed unevenly in wild plants around the tailings.

\section{Enrichment and Transfer of Heavy Metals in Plants}

Wheat, corn, and rape are major food and oil crops in norhtern China. Through the heavy-metal pollution status analysis of these 3 crops around the mining area, we can assess the risks of molybdenum mineassociated heavy metals on human health after they enter the human body through food consumption. Here we compare the enrichment and transfer coefficients of different heavy metals in crops and wormwood across different fields. We found that wormwood has a strong ability for concentrating and transferring heavy metals. The $\mathrm{Pb}$ enrichment of crops and wormwood is positively correlated with the percentage of Mo $\left(R^{2}=0.9876\right)$ and $\mathrm{Zn}\left(R^{2}=0.9918\right)$ absorption (Table 6). This is consistent with the percentage of available heavy metals in the total amount found in this study (Fig.1).

Table 6. Enrichment coefficient of heavy metals in cultivated crops (corn, wheat, rape, and apple seedling) and wild plants (wormwood) at different sampling sites.

\begin{tabular}{|c|c|c|c|c|c|c|c|c|}
\hline \multirow{2}{*}{$\begin{array}{c}\text { Heavy } \\
\text { metal }\end{array}$} & \multicolumn{2}{|c|}{ Barren land } & \multicolumn{2}{c|}{ Wheat field } & \multicolumn{2}{c|}{ Rape field } & \multicolumn{3}{c|}{ Seedling field } \\
\cline { 2 - 9 } & Wormwood & Corn & Wormwood & Wheat & Wormwood & Rape & Wormwood & Apple seedling \\
\hline $\mathrm{Cu}$ & 0.361 & 0.122 & 0.629 & 0.114 & 0.519 & 0.148 & 0.447 & 0.304 \\
\hline $\mathrm{Cd}$ & 0.384 & 0.098 & 0.699 & 0.028 & 0.761 & 0.047 & 0.305 & 0.271 \\
\hline $\mathrm{Pb}$ & 0.055 & 0.002 & 0.678 & 0.001 & 0.554 & 0.001 & 0.061 & 0.066 \\
\hline $\mathrm{Mo}$ & 0.041 & 0.015 & 0.744 & 0.009 & 0.507 & 0.006 & 0.069 & 0.085 \\
\hline $\mathrm{Zn}$ & 0.078 & 0.043 & 0.601 & 0.046 & 0.535 & 0.040 & 0.126 & 0.140 \\
\hline
\end{tabular}


Table 7. Transfer coefficient of plants at different sampling sites.

\begin{tabular}{|c|c|c|c|c|c|c|c|c|}
\hline \multirow{2}{*}{ Heavy metal } & \multicolumn{2}{|c|}{ Barren land } & \multicolumn{2}{c|}{ Wheat field } & \multicolumn{2}{c|}{ Rape field } & \multicolumn{2}{c|}{ Seedling field } \\
\cline { 2 - 10 } & Wormwood & Corn & Wormwood & Wheat & Wormwood & Rape & Wormwood & Seedling \\
\hline $\mathrm{Cu}$ & 0.227 & 0.134 & 0.412 & 0.158 & 0.393 & 0.098 & 0.352 & 0.562 \\
\hline $\mathrm{Cd}$ & 0.793 & 0.405 & 1.026 & 0.327 & 0.888 & 0.319 & 0.918 & 0.908 \\
\hline $\mathrm{Pb}$ & 0.032 & 0.246 & 0.049 & 0.230 & 0.042 & 0.286 & 0.059 & 0.170 \\
\hline $\mathrm{Mo}$ & 0.335 & 0.239 & 0.202 & 0.304 & 0.239 & 0.211 & 0.226 & 0.242 \\
\hline $\mathrm{Zn}$ & 0.808 & 0.529 & 0.846 & 0.538 & 0.693 & 0.505 & 0.587 & 0.556 \\
\hline
\end{tabular}

The enrichment coefficients of heavy metals in plants were as follows: $\mathrm{Cu}$ 0.114-0.629, Cd 0.028-0.761, $\mathrm{Pb}$ 0.001-0.678, Mo 0.006-0.744, and $\mathrm{Zn} \mathrm{0.040-0.601}$ (Table 6). The enrichment coefficients of heavy metals in wormwood and seedlings were significantly higher than those in crops, which indicates that wormwood and seedlings have a stronger ability to enrich heavy metals. The enrichment coefficients of $\mathrm{Cd}$ and $\mathrm{Cu}$ were significantly higher than those of $\mathrm{Pb}, \mathrm{Mo}$, and $\mathrm{Zn}$ in wormwood and seedlings from the seedling field, which shows that these plants have a stronger ability to absorb $\mathrm{Cd}$ and $\mathrm{Cu}$ in the seedling field. Wormwood in the wheat and corn fields has a stronger ability to enrich heavy metals, confirming that wormwood has the ability to enrich heavy metals and that long-term cultivation is favorable for absorbing heavy metals by wormwood. A similar result has been reported by $\mathrm{Li}$ et al. regarding the adsorption of soil heavy metals by weeds in a typical industrial park [42].

In terms of the transfer coefficients of heavy metals in plants, there were significant differences between different plants at different sampling sites (Table 7). The transfer coefficients of heavy metals were as follows: $\mathrm{Cu}$ 0.098-0.562, $\mathrm{Cd}$ 0.319-1.026, $\mathrm{Pb}$ 0.032-0.286, Mo 0.202-0.335, and Zn 0.505-0.846. The transfer coefficients of $\mathrm{Cd}$ and $\mathrm{Zn}$ in wormwood and crops were higher, which indicates that these two metals have higher activity in plants and can transfer from roots to shoots more easily. The rate of root-toshoot translocation is a key factor in evaluating food contamination [37]. There was a correlation $\left(R^{2}=0.8564\right)$ between the activity of heavy metals and their transfer coefficients. Abdelilah et al. reported that at a certain concentration, $\mathrm{Zn}$ promotes the absorption of $\mathrm{Cd}$ by plant roots and $\mathrm{Cd}$ transfer to the aboveground part of plants [43]. The transfer coefficient of $\mathrm{Pb}$ in wormwood was lower than that in crops and seedlings under the same conditions, which may be due to the physical attributes of wormwood; by fixing $\mathrm{Pb}$ in the root, wormwood can reduce the damage of $\mathrm{Pb}$ to the aboveground part. This is consistent with the findings of Yang et al. [44] for paddy rice in a lead-zinc mining area, and $\mathrm{Xu}$ et al. [45] for wormwood in a lead-zinc mining area. A possible reason is the retention of heavy metals by plant roots.

\section{Pollution Status of Crops}

The pollution status of crops is used to determine the food safety of crops from a particular region. For example, the grain is an edible part of corn, wheat, and rape, and heavy metals in grain can enter the human body with food and harm human health. According to the Food Standard for Limit of Pollutants in the National Food Safety Standard of China [43, 46], the Pb concentration in cereals and oil crops is $\leq 0.2$ and $\leq 0.1$ $\mathrm{mg} \cdot \mathrm{kg}^{-1}$, respectively; the $\mathrm{Cd}$ concentration in corn and wheat is $\leq 0.05$ and $\leq 0.1 \mathrm{mg} \cdot \mathrm{kg}^{-1}$, respectively; the $\mathrm{Cu}$ concentration in crops is $\leq 10 \mathrm{mg} \cdot \mathrm{kg}^{-1}$; and the $\mathrm{Zn}$ in crops concentration is $\leq 50 \mathrm{mg} \cdot \mathrm{kg}^{-1}$. Based on this standard, we assessed the pollution of heavy metals in the edible part of crops from different fields using the single and comprehensive pollution indices (Table 8).

In terms of the single pollution index, the value of $\mathrm{Cd}$ in corn at the side of the barren land was the highest (3.12), followed by that of $\mathrm{Pb}(2.48), \mathrm{Cu}(0.45)$, and $\mathrm{Zn}$ $(0.27)$. The pollution index of heavy metals in the wheat field was lower than one and ranked $\mathrm{Pb}>\mathrm{Cu}>\mathrm{Zn}=\mathrm{Cd}$. For oil plants, only $\mathrm{Pb}$ has a limit in the national standard at present, the pollution index of which was 3.42. In terms of the comprehensive pollution index, corn grain in the barren land was moderately polluted by heavy metals, and wheat grain in the wheat field was not polluted. The comprehensive pollution index of heavy metals for rape grain in the rape field could not be determined,

Table 8. Pollution indices of the edible part (grain) of crops at different sampling sites.

\begin{tabular}{|c|c|c|c|c|c|c|c|}
\hline Sampling site & Crop & $\mathrm{P}_{\mathrm{Cu}}$ & $\mathrm{P}_{\mathrm{Cd}}$ & $\mathrm{P}_{\mathrm{Pb}}$ & $\mathrm{P}_{\mathrm{Zn}}$ & $\mathrm{P}_{\text {comprehensive }}$ & Pollution level \\
\hline Barren land & Corn & 0.45 & 3.12 & 2.48 & 0.27 & 2.47 & Moderate \\
\hline Wheat field & Wheat & 0.32 & 0.24 & 0.43 & 0.24 & 0.37 & No \\
\hline Rape field & Rape & - & - & 3.42 & - & - & Yes \\
\hline
\end{tabular}


but the pollution was noted according to the single pollution index of $\mathrm{Pb}$. In summary, the crops around the molybdenum mining area are polluted, the influence of which on human health cannot be ignored.

\section{Conclusions}

This study analyzed the concentrations and forms of Mo and associated heavy metals in the soils around a molybdenum mine in Central China. The total concentrations of $\mathrm{Cu}, \mathrm{Cd}, \mathrm{Pb}, \mathrm{Mo}$, and $\mathrm{Zn}$ in bulk soils exceeded the background values. Available $\mathrm{Cd}$ (exchangeable and carbonate-bound forms) accounted for the highest percentage in the total soil concentration. The barren land and wheat field were found to be severely polluted, while the rape field and apple seedling fields were moderately polluted. The heavy-metal concentrations in different parts of crops ranked root $>$ shoot $>$ grain. The $\mathrm{Cd}$ and $\mathrm{Pb}$ concentrations exceeded the standard limit in corn grain, whereas the $\mathrm{Pb}$ concentration exceeded the standard limit in rape grain. The $\mathrm{Cu}, \mathrm{Cd}$, and $\mathrm{Pb}$ concentrations in wormwood were higher than those in general plants. The enrichment coefficients of heavy metals in wormwood and seedlings were significantly higher than those in crops, but the transfer coefficients were lower. The pollution assessment of the edible parts of crops revealed severe pollution of corn grain, pollution of rape grain, and no pollution of wheat grain. The wheat field was polluted severely, but the wheat grain was not. A higher $\mathrm{pH}$ value and organic matter content in the wheat field compared with the other fields may immobilize heavy metals in the soil. Therefore, the study of pollution problems in similar molybdenum mines should primarily consider the associated heavy metals and their existing forms; soil parameters such as $\mathrm{pH}$ and organic matter content should also be taken into consideration when determining soil pollution status.

\section{Acknowledgements}

This work was supported by the subproject of National Key Research and Development Plan "Research and Application of Common Technology of National Quality Infrastructure" (No.2017YFF0206804) and the Natural Science Basic Research Plan in Shaanxi Province of China (No. 2014JM5217)

\section{Conflict of Interest}

The authors declare no conflict of interest.

\section{References}

1. LIU Y., ZHANG W., JI P.H., YANG X. X., CAO X. F. Cadmium contamination in six kinds of vegetables in
Zhangshi irrigation area, Shenyang. Chinese Journal of Ecology. 30 (6), 1229, 2011 [In Chinese].

2. KIM C.S., STACK D.H., RYTUBA J.J. Fluvial transport and surface enrichment of arsenic in semi-arid mining regions: examples from the Mojave Desert, California. J. Environ. Monit. 14, 1798, 2012.

3. KHADIJA S., NORBERT C., SAM C. Variable element transfers from an illite-rich substrate to growing plants during a three-month experiment. Applied Clay Science, 57,17, 2012.

4. ZHANG C. QIU G.L., FENG X.B. Progress of study on mercury contamination in mercury mine environment. Chinese Journal of Ecology, 30, 5, 865, 2011 [In Chinese].

5. XIAN P.F., ZHOU S.F., WANG M.Y., WANG X.W., CHEN B.F. Extraction of molybdenum and nickel from roasted $\mathrm{Ni}-\mathrm{Mo}$ ore by hydrochloric acid leaching, sulphation roasting and water leaching. Transactions of Nonferrous Metals Society of China. 27 (1), 220, 2017.

6. WANG M.Y., WANG X.W., JIANG C.J., MA T.Q., FAN Y.Y., XIANG X.Y. Comprehensive utilization process and research status of $\mathrm{Ni}-\mathrm{Mo}$ ore [J]. Chinese Journal of Rare Metals, 36 (2), 321, 2012 [In Chinese].

7. TIMOFEEV I., KOSHELEVA N., GUNIN P., BAZHA S., ENKHAMGALAN S. Contamination of soils with heavy metals and metalloids in the vicinity of the Erdenet coppermolybdenum mining area in Mongolia. EGU General Assembly Conference Abstracts. 16, 2014.

8. CHEN H.Y., TENG Y.G., LU S.J., WANG Y.Y., WANG J.S. Contamination features and health risk of soil heavy metals in China. Science of the Total Environment, 512, 143, 2015.

9. LI Z.Y., MA Z.W., VAN DER KUIJP T.J., YUAN Z.W., HUANG L. A review of soil heavy metal pollution from mines in China: Pollution and health risk assessment. Science of the Total Environment, 468, 843, 2014.

10. HUANG J.H., YUAN F., ZENG G.M., LI X., GU Y.L., SHI L.X., LIU W.C., SHI Y.H. Influence of $\mathrm{pH}$ on heavy metal speciation and removal from wastewater using micellarenhanced ultrafiltration. Chemosphere, 173, 199. 2017.

11. FANGUEIRO D., BERMOND A., SANTOS E., CARAPUCA H., DUARTE A. Heavy metal mobility assessment in sediments based on a kinetic approach of the EDTA extraction: Search for optimal experimental conditions. Analytica Chimica Acta, 459, 245, 2002.

12. ZENG Q.D., LIU J.M., QIN K.Z., ZHOU L.L. Types, characteristics, and time-space distribution of molybdenum deposits in China. International Geology Review, 55 (11), 1311, 2013.

13. WAN D.J., HAN Z.X., LIU D.W., YANG J.S. Risk assessments of heavy metals in house dust from a typical industrial area in Central China. Human and Ecological Risk Assessment: An International Journal, 22 (2), 489, 2016.

14. TESSIER A., CAMPBELL P. G. C., BISSON M. Sequential extraction procedure for the speciation of particulate trace metals. Anal. Chem., 51 (7), 844, 1979.

15. YESILONIS I.D., JAMES B.R., POUYAT R.P., MOMEN B. Lead forms in urban turfgrass and forest soils as related to organic matter content and $\mathrm{pH}$. Environmental Monitoring \& Assessment, 146 (1-3), 1, 2008.

16. PACHECO H. P., GIL A.R., SMICHOWSKI P., POLLA G., MARTINEZ D.L. Trace aluminium determination in biological samples after microwave digestion followed by solid phase extraction with 1-methionine on controlled pore glass. Microchemical Journal, 89 (1),1, 2008. 
17. GUO X.X., LIU C.Q., ZHU Z.Z., WANG Z.L., LI J. Method for assessment on heavy metal pollution of soils. Chinese Journal of Ecology, 30 (5), 889, 2011. (in Chinese)

18. XU G., ZHANG Q.Q., JI B.Y., ZHANG Y.F., TANG J.H. Assessment on abnormal ecological effect of heavy metals in soils of Qinghai Minhe-Haishiwan area. Geoscience, 25 (5), 1007. 2011 [In Chinese].

19. XU S.Q., XU W.F., WANG Q.Y. Assessment on heavy metal pollution and potential ecological risks in river sediment in Hangzhou city. Sichuan Environment, 30 (4), 36, 2011 [In Chinese].

20. WEI S.H., ZHOU Q.X., WANG X. Study on hyperaccumulation feature of 18 kinds of weeds for heavy metals. Journal of Basic Science and Engineering, 11 (2), 152, 2003 [In Chinese].

21. LIU W.J., HU YIN, BI S.Q., LI Y.M., ZHU Y.G., LIU X.H. Study on genotypic difference of paddy rice in absorbing and transferring Arsenic at seedling stage. Chinese Agricultural Science Bulletin, 22 (6), 356, 2006 [In Chinese].

22. XUE C.Z., XIAO L., WU Q.F. Study on background values of ten elements in the main agricultural soils of Shaanxi province. Journal of Northwestern Agricultural University, 14 (3), 30, 1986 [In Chinese].

23. ZHONG L.Y., GUO L.Z. A case study of heavy metals pollution and their seasonal changes in soils with different use types in Xuwen, Guangdong province. Ecology and Environmental Sciences, 20 (12), 1934, 2011 [In Chinese].

24. XIA X., CHEN X., LIU R., LIU H. Heavy metals in urban soils with various types of land use in Beijing, China. Journal of Hazardous Materials, 186 (2-3), 2043, 2011.

25. XIAO Z.L., CONG Q., QU J. Assessment on heavy metal pollution in orchard soil around Molybdenum mining area and its influence on fruit quality. Science Technology and Engineering, 10 (23), 5831, 2010 [In Chinese].

26. HE L.P., LIU D., LIN J.J., YU Z.G., YANG X.X., FU C., LIU Z.X., ZHAO Q.H. Total nitrogen and pH-controlled chemical speciation, bioavailability and ecological risk from $\mathrm{Cd}, \mathrm{Cr}, \mathrm{Cu}, \mathrm{Pb}$ and $\mathrm{Zn}$ in the water level-fluctuating zone sediments of the Three Gorges Reservoir. Chemical Speciation \& Bioavailability, 29 (1), 89, 2017.

27. XU L., WANG T.Y., WANG J.H., LU A.X. Occurrence, speciation and transportation of heavy metals in 9 coastal rivers from watershed of Laizhou Bay, China. Chemosphere, 173, 61, 2017.

28. GUO P., XIE Z.L., LI J., KANG C.L., LIU J.H. Relationships between fractionations of $\mathrm{Pb}, \mathrm{Cd}, \mathrm{Cu}, \mathrm{Zn}$ and $\mathrm{Ni}$ and soil properties in urban soils of Changchun, China. Chinese Geographical Science, 15 (2), 179, 2005.

29. BALAKRISHNAN B., SAHU B.K., LOURDURAJ A.V., NITHYANANDAM M., PACKIRISWAMY N. Assessment of heavy metal concentrations and associated resistant bacterial communities in bulk and rhizosphere soil of Avicennia marina of Pichavaram mangrove, India. Environmental Earth Sciences, 76 (1), 58, 2017.

30. HE H.D., LI W., YU R.Q., YE Z.H. Illumina-based analysis of bulk and rhizosphere soil bacterial communities in paddy fields under mixed heavy metal contamination. Pedosphere, 27 (3), 569, 2017.

31. HUANG S.H., LI Q., YANG Y., YUAN C.Y., OUYANG K., WANG B., WAN S. Accumulation Characteristics and Chemical Speciation of $\mathrm{Cd}, \mathrm{Zn}$ and $\mathrm{Pb}$ in Soils Impacted by a Pb-Zn Mining Area. Kemija u Industriji, 66 (1-2), 53, 2017.

32. XING D., LIU H.Y., YU P.P, WU L.H. The plant community distribution and migration characteristics of heavy metals in tolerance dominant species in lead/zinc mine areas in Northwestern Guizhou Province. Acta Ecologica Sinica, 32 (3), 796, 2012 [In Chinese].

33. MARTÍNEZ A. I., CLEMENTE R., BERNAL M. P. Metal availability and chemical properties in the rhizosphere of Lupinus albus $L$. growing in a high-metal calcareous soil. Water, Air \& Soil Pollution, 201 (1-4), 283, 2009.

34. DUANMU H.S., KANG X.J., LI W.S. First exploration on supergene geochemical behavior of heavy metal elements in mine tailings. Acta Mineralogica Sinica, 31 (1), 153, 2011 [In Chinese].

35. State Environmental Protection Administration. GB 156181995, Environmental quality standard for soils. 1995 [In Chinese].

36. GUAN G.C., XU S., HUANG J.G. Analysis on distribution, change and transfer rules of heavy metals in soil-paddy system. Ecological Environment, 15 (2), 315, 2006 [In Chinese].

37. CLEMENS S., MA J.F. Toxic heavy metal and metalloid accumulation in crop plants and foods. Annual Review of Plant Biology, 67 (1), 489, 2016.

38. National Health and Family Planning Commission of the People's Republic of China. GB 2762-2017, National standards for food safety - contaminants limit in food. 2017 [In Chinese].

39. WANG Y., ZHAO Q.L., HU Y., DU X., GE W., LIU W.J. Survey and contamination assessment of Heavy metals in in soils and plants around the $\mathrm{Pb}-\mathrm{Zn}$ mining in Shangyu Zhejiang province. Environmental Chemistry, 30 (7), 1354, 2011 [In Chinese].

40. SUN X. C., HU C. X., TAN Q. L., LIU H.E. Endogenous hormone in response to molybdenum in winter wheat roots under low temperature stress. Journal of Food, Agriculture and Environment, 8, 597, 2010.

41. HENRIQUES A.R., CHALFUN-JUNIOR A., AARTS M. Strategies to increase zinc deficiency tolerance and homeostasis in plants. Brazilian Journal of Plant Physiology, 24 (1), 3, 2012.

42. LI F.Y., XIAO P.F., HOU W., GUAN W., WANG X.J., MA X.P. Study on the absorption feature of typical industrial park's weeds for heavy metals in soils. Journal of Liaoning Technical University, 26 (2), 300,2007 [In Chinese].

43. ABDELILAIH C., MOHAMED H.G., EZZEDINE E.F. Effects of cadmium-zinc interactions on hydroponically grown bean (Phaseolus vulgaris L.). Plant Science, 126, 21, 1997.

44. YANG Q.W., SHU W.S., LIN Z., LIN L., ZOU H.L., LAN C.Y. Assessment on combined contamination and ecological impact of heavy metal in wastewater of $\mathrm{Pb}-\mathrm{Zn}$ mine on soil-paddy rice. Journal of Agro-Environment Science, 22 (4), 385, 2003 [In Chinese].

45. XU H.W., ZHANG R.Z., XIE Y. Absorption and concentration features of the pioneer plant Artemisia lavandulaefolia $D C$ for heavy metals in Pd-Zn mining area. Journal of Agro-Environment Science, 28 (6), 1136, 2009. [In Chinese].

46. The Ministry of Agriculture of the People's Republic of China. NY 861-2004, Limits of eight elements in cereals, legume, tubes and its products. 2004 [In Chinese]. 
